\title{
Influence Of Emotional And Spiritual Intelligence Towards Intention To Stay By Generation Y Employees In The Information And Communication Technology Sector In Malaysia: The Mediating Role Of Perceived Organizational Support
}

\author{
Ayshani Weeratunga, Jugindar Singh Kartar Singh
}

\begin{abstract}
The digital industry in Malaysia employs an estimated 355,000 employees and the average attrition rate was $17 \%$ in 2017. The Millennials or the Generation $Y$ were born in between 1980 to 1993 that would formulate $75 \%$ of the labor force by 2025. However, Gen $Y$ workforce are hard to maintain as they are primarily concerned on temporary job prospects and immediate outcomes. Gen Y employees contribute to greater level of turnover rate and retaining them is a significant challenge for the organizations. This paper presents a review of the intention to stay by Gen $Y$ employees in Malaysia. This study will answer three questions. Firstly, this study will examine the concept of emotional intelligence used to retain Gen Y employees. The next question is to what extend does spiritual intelligence influence Gen $Y$ intention to stay. The last question is whether perceived organizational support (POS) mediates the relationship between the constructs. The study aims to accentuate the key role of emotional and spiritual intelligence towards retaining Gen $Y$ employees. A literature review on relationships between emotional intelligence, spiritual intelligence and intention to stay was examined. The examination concluded that higher level of emotional intelligence and spiritual intelligence are positive predictors of intention to stay. This study revealed that POS has both direct and indirect relationships between several organizational outcomes. There is a rareness of studies in the background of the role of emotional and spiritual intelligence and perceived organizational support of Gen Y employees. With the anticipated increase of Gen $Y$ employees, this study will establish a better understanding and knowledge about Gen $Y$ and offer them accurate tools to cooperate and manifest the accurate solutions. The findings are expected to present new insights in the manner of how Gen $Y$ employees' emotional and spiritual intelligence can contribute towards their intention to stay longer.

Index Terms: Emotional intelligence, Generation Y, Intention to stay, perceived organizational support, Spiritual Intelligence.
\end{abstract}

\section{INTRODUCTION}

Malaysia is a newly industrialized country and the government has recognized the ICT sector as the leading financial arena that would contribute to accelerate the production and ultimately raise the country's competency in accomplishing the goal of becoming a progressive national by 2020 [1]. The ICT sector is a substantial influencer for the country's growth. In the year 2017, the sector has

Revised Manuscript Received on April 19, 2019.

Ayshani Weeratunga, School of Management, Asia Pacific University of Technology and Innovation, Kuala Lumpur, Malaysia.

Jugindar Singh Kartar Singh, School of Management, Asia Pacific University of Technology and Innovation, Kuala Lumpur, Malaysia. contributed RM 247.1 billion that signifies a share of $18.3 \%$ to the entire economy, whereas the contribution to the Gross Domestic Product (GDP) verified growth of $8.4 \%$ with a value of RM 178.2 Billion [2]. Correspondingly, ICT sector has contributed $7.6 \%$ to the total employment which accounts for 1.09 million in the year 2017 [2]. Over $21 \%$ of Malaysia's GDP will be digitalised by 2022 , with growth in every industry driven by digitally enhanced offerings, operations and relationship [3]. The statistical data provides a clear indication on the significant contribution of the ICT sector to the country's economy.

Presently, Gen Y is the largest generation with a count of 2.5 billion worldwide. The Gen Y are born between year 1980 to 2000 and they will represent $75 \%$ of the workforce by 2025 [4]. According to Labour Force Survey Report Malaysia (2014) by Department of Statistic Malaysia, roughly $60 \%$ of the total workforce in Malaysia is formed by the Gen Y employees [5]. Gen Y employees grew in a comfortable manner, technology savvy and suffer less in the grown process. In a working environment, Gen Y employee are seen as adaptable and talented employees who can carry out their responsibilities more creatively, innovatively, effectively and efficiently [6]. Furthermore, Gen Y employees are keen on acquiring different experiences at several diverse work surroundings. However, Gen Y employees pose a challenge to organizations because they focus on the short-term job opportunities. Generation Y employees look for rapid career growth, ongoing feedback from organizations and an interesting career [7]. Due to the short-term job circles, Gen Y employees contribute towards higher level of employee turnover. Therefore, millennials will be a powerful generation of employees but retaining Gen $\mathrm{Y}$ employees in organizations is a challenge for the employers. It is essential for organizations to have a thorough understanding about Gen Y needs and expectations in order to retain them.

Vast variety of studies have identified the elements that emphasis on Gen Y employees' intention to remain in conglomerates. Aa research conducted by [8], concepts such as training, empowerment, organizational commitment and

Published By:

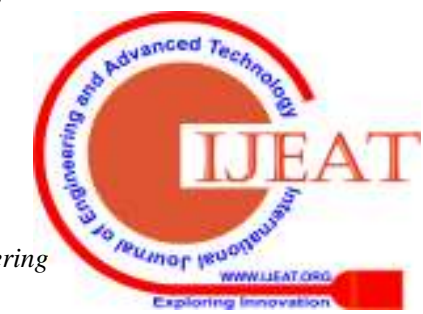


career planning were recognized as the aspects influencing in retainment of the employees. The survey by [7] acknowledged that speedy advancement, a diverse and fascinating career and consistent response as the aspects influencing Gen Y workforce to remain in an organization. [9] identified extrinsic rewards, work life balance, status work values, availability of alternative jobs as factors that affect retention. The additional aspects that encourage Gen $\mathrm{Y}$ workforce to continue the employment for a longer time period encompasses among other things a good career path, good compensation and benefits package and ongoing development [10]. Therefore, there are countless elements that encourage an employee sustain longer in a conglomerate. It is noted that previous studies concentrated mostly on intention to leave [11], [12]. Previous researches have established the fact that intention to remain and intention to quit are not determining the identical paradigms [13]. The construct of intention to remain is a predictor of job satisfaction nevertheless intention to quit is not a predictor of job satisfaction [13]. The current researcher intends to study on intention to stay by Gen Y employees in the ICT sector.

Cost of employee leaving an organization is immense and due to the level of employment, it might regularize one and half times the employee's entire yearly reward [14]. Additionally, replacing cost of the human resource could fall in under the range of 90 to $100 \%$ of an employee's yearly income [15]. The ICT sector have the highest employee turnover rate in Malaysia compared to the other different industries [16]. Despite the challenges faced by conglomerates, there is a dearth of research on Gen Y employees' intention to stay in the ICT sector in Malaysia. Additionally, the influence of emotional and spiritual intelligence towards intention to stay with the mediating role of perceived organizational support has not empirically tested among Gen Y employees in the ICT sector in Malaysia. This paper posits that emotional, spiritual intelligence and perceived organizational support will contribute positively towards intention to stay longer by Gen Y employees. The results of this research could contribute to the HR mangers to understand the importance of adopting emotional and spiritual intelligence to enhance the Gen Y employees' intention to stay.

\section{LITERATURE REVIEW}

\section{Intention to stay}

Researchers and scholars have defined employees' intention to remain in employment for longer period in organizations and the constructs that influence their intention to remain in employment in same organization [17] - [18]. Intention to stay refers to the willingness of the employees to continue working in an organization [18]. Similarly, [17] explained that intention to stay refers to the employees' propensity to remain working with the current organization. [19] further included the employee commitment and stated that intention to stay refers to and employee's willingness to remain working in the current organization and his/her level of commitment. From the psychological perspective, [20] stated that intention remain working in the current organization is a procedure of psychological connection with the company. An employee's intention to remain working for a longer period in an organization can be explained by the Social Exchange Theory and the Theory of Planned Behaviour. The employee's intention to involve in a certain behavior and the actual engagement in that behavior can be explained by the Theory of Planned Behaviour (TPB) [21]. According to the Theory of Planned Behaviour, an employee's intention to remain working in the current organization can be influenced or predicted through attitude of the employee, subjective norms and perceived behavioral control. These three constructs predict the behavioral intention and the actual intention to stay in an organization [21]. However, as explained by [21], actions are controlled by intentions, but not all intentions are carried out by employees. The Social Exchange Theory (SET) by [22], focus on the understanding of relationships, the underpinning mechanisms and the outcomes. Practically, as explained by the Social Exchange Theory, good deeds by employers can be used to explain the reasons why employees have relationships with them. In short, good deeds by employers need to be reciprocated by employees [23]. A study was done by Jones and Volpe [24] based on the organizational identification theory and the social exchange theories. The study by Jones and Volpe [24] found that that employees' attitude predicted outcomes such as intention to remain in the current organization through its effect on organizational identification.

Previous researchers and scholars have identified several predictors that impacts Gen Y employees to continue employment for a longer time period in a conglomerate. [25] studied employee commitment and found out that affective commitment, normative commitment and goal clarity had a substantial effect on employees' intention to continue working in the current organization. [26] studied the work environment and found a positive affiliation among work environment and employees' intention to remain in the current organization. Researchers have examined and found a relationship between the workplace and intention to remain working in the same organization. [27] and [28] focussed on workplace spirituality and stressed that that workplace spirituality had a positive influence towards employees' intention to remain with their current employer. [18] stated that mentoring has a direct influence on the intention to remain in the current organization by Gen $\mathrm{Y}$ employees'. [10] identified that training and development, compensations and benefits and transformational leadership style have a potentially positive connection with Gen Y employees' intention to stay. Knowledge sharing is another significant construct to foster growth of competencies and create a logic that affect Gen Y employees' intention to stay [29]. [30] directed a research on Gen $Y$ employees in Malaysia and the results of the study revealed that Generation Y workforce favour flexible working hours and a decent work-life balance to remain longer with their organizations. [31] and [32] identified career growth and development as a positive predictor of Gen $\mathrm{Y}$ intention to 
stay. [32] explained the Gen Y intention to stay longer is related to their competency development that evokes affective commitment. Based on past research, there are several predictors of intention to stay among Gen Y employees.

\section{Emotional intelligence and intention to stay}

Emotional intelligence is gaining interest among researchers and organizations. However, there are different viewpoints, dimensions and definitions of emotional intelligence among researchers and scholars [33], [34]. Based on the ability model, emotional intelligence refers to an individual's set of mental abilities. The set abilities encompass perceiving emotions, understanding emotions, using emotions and regulating emotions in self and others [34]. Emotional intelligence combines emotions and intelligence that include practical, social and personal intelligences [35]. [35] referred to emotional intelligence as a person's capacity and ability to reason about his/her emotions using emotions to improve his/her thinking. Another approach of looking at emotional intelligence is the trait or competency approach. Based on the concept of emotional intelligence, [33] proposed a framework of personal competencies. Emotional intelligence is referred to as a wide array of competencies and skills by [33]. [36] looked at emotional-social intelligence. This model stressed the crucial role of emotional expression. The Bar-On model [36] of emotional-social intelligence stresses the importance of social expression and explains how individuals express themselves, understand others and relate with them, and cope with daily demand. Emotional intelligence was categorized into four dimensions by [37]. The four dimensions by [37] are self-awareness, self-management, social awareness, and relationship management. [38] stated that the bedrock of emotional intelligence is self-awareness because if an individual does not understand his/her own motivations and behavior, it is impossible to develop an understanding of others. [33] emphasized that empathy is a crucial component of social awareness because through empathy an individual can learn to see things learning from another person's perspective and understand them better. [39] explained that individuals have different abilities in perceiving, understanding, utilizing and managing emotions and these varieties influence persons' adaption in diversified contexts.

Several scholars and researchers have found that emotional intelligence had a positive influence on organizational outcomes and as stated by [40], employees' performance may be more effective due to higher levels of emotional intelligence. [33] further stressed the effective role of emotional intelligence and stated that emotional intelligence is most important determinant of leadership success. The positive role of emotional intelligence is supported by several other studies [41], [42], [43]. The study by [42] found that job performance of employees was influence by emotional intelligence. Another study by [41] found high levels of correlation between emotional intelligence and job performance. A study done in Malaysia by [44] revealed that all the four components of emotional intelligence namely self-awareness, self-regulation, selfmotivation, empathy, and social skills had a significant effect on job performance. Similarly, [45] found that emotionally intelligent leaders achieve better organization performance results. This was supported through emotional intelligence tests where employees who possess higher emotional intelligence obtained higher performance evaluation from superiors, peers and assistants [46], [47], [48], [49]. Studies using the attribute or aptitude approach showed that employees who possess higher emotional intelligence were found to be better performers [48], [49]. From the perspective of relationships, studies have shown that employees who possess greater level of emotional intelligence are better at developing and preserving quality relationships [50]. However, there is some arguments among researchers on the relationship between emotional intelligence, cognitive intelligence and job performance of employees. [40] explained that emotional intelligence is closely related to cognitive intelligence but both are distinct constructs. [40] argued that employees with low level of cognitive intelligence may reap relatively large returns from high emotional intelligence.

There are limited studies on the positive influence of employees' emotional intelligence and employees' towards their intention to stay longer in their current organization. A study by [51] revealed that employees' emotional intelligence was a predictor of employee turnover intentions. According to [51], employees can develop stronger and higher relationships if they possess higher levels of emotional intelligence. Another study by [52] revealed that an increase in the turnover of nurses was due to factors that encompass emotional labor, job stress and burnout. The study by [52] found that there was an inverse relationship between emotional intelligence and emotional labor. Higher level of emotional intelligence will lead to the reduction of job stress, burnout and eventually the intention to leave an organization. This means that higher levels of emotional intelligence contribute towards lower turnover intentions. [53] found that emotional intelligence and resilience of a salesperson reduces the intention to leave their organization, through the alleviation of work-family conflict and emotional exhaustion. On the contrary, a study by [54] found that there was no significant inverse relationship between turnover intention and emotional intelligence. This can be contributed to cultural differences.

\section{Relationship between spiritual intelligence and intention} to stay

The concept of spiritual intelligence was stated by [55], followed by [56]. Spiritual intelligence was referred to as an individual's ability and capacity to resolve his or her problems and achieve his or her goals [57]. Based on this definition by Emmons [57], the spiritual intelligence among employees in organizations can lead to higher levels of job performance, efficiency and productivity. [58] defined spiritual intelligence as a collection of mental capabilities grounded on unsubstantial and glorious features of life There are also several components or dimensions of spiritual intelligence stated by different scholars. Emmons [57] 
identified five dimensions or components of emotional intelligence. King [58] refereed to spiritual intelligences as a set of mental capacities of individuals and designed a valid measure of spiritual intelligence. The model developed by king [58] had 4 components. [59] explained the seven stages of spiritual intelligence that encompass awareness, meaning, evaluation, being centered, vision, projection and mission. According to [60], spiritual intelligence is the ability to act with wisdom and compassion, preserving the internal and external peace captivating the circumstances into consideration. [56] further stated that spiritual intelligence concentrates on the capabilities that attracts spiritual themes that forecast functioning, adaptation and the ability to manufacture valuable products and services. [61] defined spiritual intelligence as the capability in identifying and resolving problems of meaning and value. According to Vaughn [62], spiritual intelligence is concerned its relationship to being in the world and this can be developed in individuals through inquiry and practice. [63] shifted from mental ability and intelligence and described spiritual intelligence as more of a heightened consciousness.

Spiritual intelligence of employees is now widely studied, and studies have shown that a positive relationship between spiritual intelligence several work-related outcomes exist [57], [64]. The stronger level of spiritual intelligence in individuals leads to development and improvement of outcomes in the workplace [57]. Greater level of spiritual intelligence in individuals was also positively related to improvement in the level of job performance [65] - [64]. The positive influence of spiritual intelligence towards job satisfaction subsequently leads to higher levels of job performance [66]. Studies have shown that spiritual intelligence had a direct and indirect influence on the dimensions of job performance namely task performance and contextual performance [67]. Since, employee performance includes both task and contextual, spiritual intelligence had a positive influence on overall performance. Another study by [68] showed that spiritual intelligence is related to happiness of employees. Studies have shown that happiness leads to job satisfaction and other outcomes. [69] looked at employee engagement and found that spiritual intelligence was a positive predictor of employee engagement.

There is a dearth of studies on the effect of spiritual intelligence towards the employees' intention to remain or leave their current organization. A study by [70] found that spiritual intelligence was one of the determinant of employees' intention to stay or leave their current organization. According to the study, there was a difference between the managers and employees' perception concerning the tactics for spiritual management. In the study, it was revealed that the managers placed more emphasis on the tangible aspects, but the employees placed more emphasis on the intangibles. Another study by [71] found that the five spirituality dimensions were related to the affective, normative and continuance forms of commitment. The findings suggest that when employees feel more affectively attached to organizations when the experience workplace spirituality. Therefore, spiritual intelligence will increase the work performance, enhance the relationships among the employees, boost the job satisfaction and reduces the turnover intention [72], [73].

The mediating role of Perceived Organizational Support (POS)

From the organizations perspective, perceived organizational support (POS) is the level or degree to which a particular organization values the contribution by the employees. From the employees' perspective, perceived organizational support refers to their perception on the degree to which the employer values their contribution and cares about their wellbeing [74]. [75] explained that perceived organizational support (POS) is a feeling of obligation to care about the organization. POS is equally valuable to employees and the organizations and it is a vital factor to strengthen the employer-employee relationships [76]. POS describes the circumstances where employees observe that their work and contributions are appreciated, and they are supported and cared by the respective organizations [77]. Additionally, [78] explained that POS is employees' trust that an organization rewards them for the dedication they put in. The organizational support theory could be utilized to comprehend the background and significances of POS. According to the organizational support theory [74], [78], to analyse the rewards of increased work dedication, employees generate an allpurpose awareness concerning the level to which, where the organization value employees' contribution and cares for their well-being. Grounded on the organizational support theory, POS is appreciated by employees because it provides the requirements for connection and esteem [79]. The organizational support theory describes how POS generates positive results for employees and conglomerates. Hence, it is important for conglomerates to implement strategies that would enhance POS a where employees are valued and feel the connectivity to the conglomerate.

POS is related to several organizational outcomes. [80] found that POS is positively related with confidence, respect and association with the organization. A research conducted by [81] stated that POS had a positive impact on job performance and strengthened the influence of accomplishment on job performance. According to Weiss and Cropanzano [82], employees react emotionally to events in organizations. The employees' attitudes and behaviors are subsequently affected by such events or experiences. The beginning of an assessment of work in the organization forms an individual's personal emotional reaction, which then forms an affective commitment and work behaviours. In addition, effective experiences regarding the degree to which the organization value the contribution and cares about the employees is a main feature in persuading the use of emotional strategies [83]. The employees with greater level emotional intelligence and the employees' perception of greater level of organizational support; encourages employees to use the capabilities to the maximum level. Studies have shown that employees who scored in greater self-esteem functioned well with the support of the 
organization [84]. A research conducted by [85] indicated that self-esteem was positively related to work productivity and sense of belonging to the organization. Similarly, [86] anticipated that employees can be motivated by achievement accomplished in the organization, which in return emphasised a willingness to stay in the present organization. Therefore, when employees accomplish professional success, the employees develop greater level of self-esteem and capability to cope up with negative emotions, which would ultimately increase the intention to remain [87].

Evidence from previous studies demonstrated that POS have a connection towards intention to stay. [74] stated that POS primarily focused on the relationship with organizational commitment (OC). [88] further stated that in addition to commitment, POS also influence intention to stay. [78] mentioned three main groups of beneficial treatments received by employees namely fairness, supervisory support, organizational rewards and favourable job conditions were linked with POS. In return POS was linked to results favourable towards the employees that include job satisfaction and positive moods and towards the organization. This encompass affective commitment, performance and lessened withdrawal behaviour. Similarly, POS has a positive influence over employee attitude and behaviour that is due to POS that creates a perception of responsibility within the employees to be gratified [74], [89]. A research done by [90], [87] found that POS was connected to higher performance, intention to stay and related positive results in conglomerates. However, a study conducted by [91] revealed that only perceived organizational support had a positive influence over intention to stay. [79] clarified that POS was aligned to the employees' beliefs about the company and resulted in higher intention to stay. Overall, it can be concluded that the positive consequence of POS is the establishment of strong relationship between employees and employers and employees are a valuable resource to organizations.

Previous studies have revealed that POS is a mediator amongst various organizational outcomes. The study conducted by [92] revealed the POS completely mediated the effect of interpersonal and informational justice on citizenship behaviours that are directed at the organization and its members. A study by [93] showed a positive role of POS between several constructs that include leadership, organizational justice and leader member exchange. Another study conducted by [94] revealed that the relationship between job insecurity and organizational citizenship behaviour and job performance was fully mediated by POS. The study by [87] discovered that POS positively influenced intention to remain and career progression, which on the other hand mediated among POS and intention to stay. Organizational support theory [79] describes the way in which POS develops and generate positive consequences for employees and organizations. As stated by [79] POS is beneficial for conglomerates as the level of commitment of employees would enhance. The employees who have immensely dedicated towards the firm, has a greater percentage of boosting the performance and remaining longer time period in an organization. Therefore, as mentioned in several studies, it appears to be that POS played the role of a mediator between several organizational outcomes. Based on the evidence above on the role of POS as a mediator amongst various variables, the researcher believes that relationship of emotional and spiritual intelligence and intention to stay is mediated by POS.

\section{CONCLUSION}

In today's globalized environment where the pace of changes is ever increasing, the work demands on emotional intelligence and spiritual intelligence is becoming increasingly important. In view of the challenges faced by organizations in relation to the retention of Gen $y$ employees. The focus of this study was to improve the retention of Gen Y employees. At the heart of this study was the role of emotional intelligence, spiritual intelligence and POS. The results of this study revealed that spiritual intelligence and emotional intelligence are positively related to employees' intention to stay. This review found the dominant role of spiritual intelligence and emotional intelligence in organizations today. Both emotional intelligence and social intelligence are key indicators of employees' intention to remain with their current organization. Higher level of spirituality of employees in the workplace leads to improved ethical behaviour. The ethical behaviour leads to an enhanced ethical climate that supports higher performance of employees at the workplace and intention to stay [95]. Furthermore, employees' who are in control of their feelings and impulses can create an environment of trust where superior performance can be achieved [33]. An emotionally intelligent employee with higher personal competence and social competence can contribute better towards occupational success and stay longer with the organization [33]. It can be assumed that emotional intelligence and spiritual intelligence complement each other. This means that both emotional intelligence and spiritual intelligence competencies are critical for success in workplace outcomes including employees' intention to stay. POS has direct and indirect relationship between the constructs in this study. Therefor POS is beneficial for organizations because the commitment level of employees will increase. Employees who are committed are likely to increase performance and stay longer in organizations.

To succeed in today's digitalised Industry 4.0 world and knowledge-based economy, organizations need to invest in programs and activities to promote the development of human capital. Organizations should recognize the importance of emotional intelligence and spiritual intelligence and take steps to implement internal policies. Human resource managers need to understand the concepts of emotional intelligence and spiritual intelligence and formulate support strategies and training programs to improve the emotional and spiritual intelligence levels of employees. Organizational leaders should also implement policies and practices to enhance Gen Y employees' perception of the organization in valuing their work and supporting their well-being to increase their commitment and intention to stay. 


\section{REFERENCES}

1. Saleh S, and Ramasamy, R. Capability of the Information and Communication Technology Services sector in Malaysia: An industry perspective ICT Strategic Review 2013/2014 The Digital Opportunity. 2013.

2. Information and Communication Technology Satellite Account, 2017. [Internet]. Department of Statistics Malaysia. 2018 [cited 12 March 2019]. Available from: https://www.dosm.gov.my/v1/index.php?r=column/cth.

3. Sidhu KK. Avoid home loan rejection with propertyguru's fintech solution. Digital News Asia.; 2019.

4. Savvy Gen Y-The workforce in the future. [Internet]. The Malaysian Reserve. 2019 [cited 12 january 2019]. Available

from: https://themalaysianreserve.com/2017/03/31 savvy-gen-y.

5. Yahya KK, Tee C-W, Johari J. Employee Engagement: A Study on Gen $\mathrm{Y}$ in the Manufacturing Industry. Journal of Business and Social Review in Emerging Economies. 2018;4(1):37-44.

6. St Claire-Ostwald B. How to coach generation $y$. Coaching At Work. 2012;7(6):54-5.

7. Millennials at work: Reshaping the workplace. [Internet]. PWC. 2011. [cited 15 February 2019]. Available from: https://www.pwc.de/de/prozessoptimierung.

8. Queiri A, Dwaikat N. Factors affecting Generation Y employees' intention to quit in Malaysian's business process outsourcing sector. Journal of Sustainable Development. 2016;9(2):78.

9. Queiri A, Yusoff WFW, Dwaikat N. Explaining Generation-Y employees' turnover in Malaysian context. Asian Social Science. 2015;11(10):126.

10. Othman SZ, Lembang SA. What Attract Gen Y to Stay in Organization? HR Practices, Organizational Support or Leadership Style. International Review of Management and Marketing. 2017;7(2):1-9.

11. Allen DG. Do organizational socialization tactics influence newcomer embeddedness and turnover? Journal of management. 2006;32(2):237-56.

12. Spreitzer GM, Mishra AK. To stay or to go: Voluntary survivor turnover following an organizational downsizing. Journal of Organizational Behavior: The International Journal of Industrial, Occupational and Organizational Psychology and Behavior. 2002;23(6):707-29.

13. Nanncarrow S, Bradbury J, Pit SW, Ariss S. Intention to stay and intention to leave: are they two sides of the same coin? A cross-sectional structural equation modelling study among health and social care workers. Journal of occupational health. 2014:14-0027-OA.

14. Cappelli P, Keller JR. Classifying work in the new economy. Academy of Management Review. 2013;38(4):575-96.

15. Wilson C. Retaining good people through a focus on talent and purpose: Proper inductions make employees feel as though they truly belong. Human Resource Management International Digest. 2012;20(2):29-31.

16. Hewitt A. With Voluntary Employee Turnover on the Rise, Technology Sector Companies in Singapore and Asia-Pacific Boost 2017 Salary Budgets Singapore.; 2016.

17. Currivan DB. The causal order of job satisfaction and organizational commitment in models of employee turnover. Human resource management review. 1999;9(4):495-524.

18. Naim MF, Lenka U. How does mentoring contribute to Gen Y employees' intention to stay? An Indian perspective. Europe's journal of psychology. 2017;13(2):314

19. A. H. Strategies for Cost Management of the HR Function. Timely Topics Survey Results 2004.
20. Hunjra AI, Ali MA, Chani D, Irfan M, Khan H, Rehman KU. Employee voice and intent to leave: An empirical evidence of Pakistani banking sector. African Journal of Business Management. 2010;4(14):3056-61.

21. Ajzen I. The theory of planned behavior. Organizational behavior and human decision processes. 1991;50(2):179211.

22. Thibaut J. Kelley. HH (1959). The social psychology of groups.

23. Blau PM. Exchange and power in social life. New York: John Wiley and Sons. Inc; 1964.

24. Jones C, Volpe EH. Organizational identification: Extending our understanding of social identities through social networks. Journal of organizational behavior. 2011;32(3):413-34.

25. Ghosh P, Satyawadi R, Prasad Joshi J, Shadman M. Who stays with you? Factors predicting employees' intention to stay. International Journal of Organizational Analysis. 2013;21(3):288-312.

26. Al-Hamdan Z, Manojlovich M, Tanima B. Jordanian nursing work environments, intent to stay, and job satisfaction. Journal of Nursing Scholarship. 2017;49(1):103-10.

27. Aboobaker N, Edward M. Workplace spirituality, employee wellbeing and intention to stay: A multi-group analysis of teachers' career choice. International Journal of Educational Management. 2019;33(1):28-44.

28. Milliman J, Gatling A, Kim JS. The effect of workplace spirituality on hospitality employee engagement, intention to stay, and service delivery. Journal of Hospitality and Tourism Management. 2018; 35:56-65.

29. Naim MF, Lenkla U. Knowledge sharing as an intervention for Gen Y employees' intention to stay. Industrial and Commercial Training. 2016;48(3):142-8.

30. Hossain MI, Limon, N., Amin, M.T. and Asheq, A.S. Work Life Trends: A study on Malaysian Generation Y Bankers. IOSR journal of Business and Management 2018;20(9):01-9.

31. Brown EA, Thomas NJ, Bosselman RH. Are they leaving or staying: A qualitative analysis of turnover issues for Generation Y hospitality employees with a hospitality education? International Journal of Hospitality Management. 2015; 46:130-7.

32. Naim MF, Lenka U. Development and retention of Generation Y employees: a conceptual framework. Employee relations. 2018;40(2):433-55.

33. Goleman D. Working with emotional intelligence: Bantam; 1998

34. Mayer JD. Salovey. P.(1997). What is emotional intelligence. Emotional development and emotional intelligence: Educational implications. 2010:3-31.

35. Mayer JD, Salovey P, Caruso DR. TARGET ARTICLES:" Emotional Intelligence: Theory, Findings, and Implications". Psychological inquiry 2004;15(3):197-215.

36. Bar-On R. The Bar-On model of emotional-social intelligence (ESI). Psicothema. 2006;18.

37. Goleman D, Boyatzis R. McKee. (2002). Primal leadership: Realizing the power of emotional intelligence. 2002

38. The Bedrock of EI: Self-Awareness [Internet]. People skills bootcamp.com. 2017. W.-K. Chen, Linear Networks and Systems (Book style). Belmont, CA: Wadsworth, 1993, pp. 123-135. 
39. Cherniss C. Emotional intelligence: Toward clarification of a concept. Industrial and Organizational Psychology. 2010;3(2):110-26.

40. Cote S, Miners CT. Emotional intelligence, cognitive intelligence, and job performance. Administrative Science Quarterly. 2006;51(1):1-28.

41. Stein SJ, Book HE. The EQ edge: Emotional intelligence and your success: John Wiley \& Sons; 2011. emotional intelligence on performance and attitude: An exploratory study. The leadership quarterly. 2002;13(3):243-74.

43. Lam LT, Kirby SL. Is emotional intelligence an advantage? An exploration of the impact of emotional and general intelligence on individual performance. The journal of social Psychology. 2002;142(1):133-43.

44. Mohamad M, Jais J. Emotional intelligence and job performance: A study among Malaysian teachers. Procedia Economics and Finance. 2016; 35:674-82.

45. Carmeli A. The relationship between emotional intelligence and work attitudes, behavior and outcomes: An examination among senior managers. Journal of managerial Psychology. 2003;18(8):788-813

46. Brackett MA, Rivers SE, Salovey P. Emotional intelligence: Implications for personal, social, academic, and workplace success. Social and Personality Psychology Compass. 2011;5(1):88-103.

47. Iliescu D, Ilie A, Ispas D, Ion A. Emotional intelligence in personnel selection: Applicant reactions, criterion, and incremental validity. International Journal of selection and Assessment. 2012;20(3):347-58.

48. Joseph DL, Newman DA. Emotional intelligence: an integrative meta-analysis and cascading model. Journal of applied psychology. 2010;95(1):54.

49. O'Boyle Jr EH, Humphrey RH, Pollack JM, Hawver TH, Story PA. The relation between emotional intelligence and job performance: A meta-analysis. Journal of Organizational Behavior. 2011;32(5):788-818.

50. Lopes PN, Salovey P, Straus R. Emotional intelligence, personality, and the perceived quality of social relationships. Personality and individual Differences. 2003;35(3):641-58

51. Jordan PJ, Troth A. Emotional intelligence and leader member exchange: The relationship with employee turnover intentions and job satisfaction. Leadership \& Organization Development Journal. 2011;32(3):260-80.

52. Hong E, Lee YS. The mediating effect of emotional intelligence between emotional labour, job stress, burnout and nurses' turnover intention. International journal of nursing practice. 2016;22(6):625-32.

53. Bande B, Fernández-Ferrín P, Varela JA, Jaramillo F Emotions and salesperson propensity to leave: The effects of emotional intelligence and resilience. Industrial Marketing Management. 2015; 44:142-53.

54. Saeed I, Waseem M, Sikander S, Rizwan M. The relationship of turnover intention with job satisfaction job performance, leader member exchange, emotional intelligence and organizational commitment. International Journal of Learning and Development. 2014;4(2):242-56.

55. Barnum BS. Spirituality in nursing. From Traditional to New Age. 1996.

56. Emmons RA. The psychology of ultimate concerns: Motivation and spirituality in personality: Guilford Press; 1999.

57. Emmons RA. Spirituality and intelligence: Problems and prospects. The international journal for the psychology of religion. 2000;10(1):57-64.

58. King U. The search for spirituality: Our global quest for a spiritual life: BlueBridge; 2008.
42. Wong C-S, Law KS. The effects of leader and follower

59. Bowell RA. The seven steps of spiritual intelligence: The practical pursuit of purpose, success, and happiness Nicholas Brealey Publishing; 2004.

60. Wiggleworth C. Why Spiritual Intelligence Is Essential to Mature Leadership President, Couscious Pursuits. Inc; 2006.

61. Zohar D, Marshall I, Marshall I. SQ: Connecting with our spiritual intelligence: Bloomsbury Publishing USA; 2000.

62. Vaughan F. What is spiritual intelligence? Journal of humanistic psychology. 2002;42(2):16-33.

63. Mayer JD. Spiritual intelligence or spiritual consciousness? The international Journal for the Psychology of Religion. 2000;10(1):47-56.

64. Hanafi R. Spiritual Intelligence, Emotional Intelligence and Auditor's Performance. Jurnal Fakultas Hukum UII 2010;14(1).

65. Utomo HJN, Nimran U, Hamid D, Utami HN. The effect of spiritual and emotional intelligence on the job satisfaction and organizational commitment: Study on salespersons of motorcycles in special region of Yogyakarta. International Journal of Management and Administrative Sciences. 2014;4(1):74-83

66. Ali Shah T, Ellahi A, editors. Workplace spirituality, emotional intelligence and job satisfaction: Pakistani managers in focus. International Conference on Management (2nd ICM 2012) Proceeding International Conference on Humanities, Economics and Geography March; 2012.

67. Upadhyay S. Can Spiritual Intelligence Influence Research Performance in Higher Education? Framework for Human Resource Development in Higher Education. Revista» Administratie si Management Public «(RAMP). 2017(28):153-73

68. Faribors B, Fatemeh A, Hamidreza H. The relationship between nurses' spiritual intelligence and happiness in Iran. Procedia-Social and Behavioral Sciences. 2010 5:1556-61.

69. Devi S. Impact of spirituality and emotional intelligence on employee engagement. International Journal of Applied Research. 2016;2(4):321-5.

70. Lee T-R, Chen S-Y, Wang S-H, Dadura A. The relationship between spiritual management and determinants of turnover intention. European Business Review. 2010;22(1):102-16.

71. Rego A, Pina e Cunha M. Workplace spirituality and organizational commitment: an empirical study. Journal of organizational change management. 2008;21(1):53-75.

72. Frew DR. Transcendental Meditation and productivity Academy of Management Journal. 1974;17(2):362-8.

73. Alexander CN, Swanson GC, Rainforth MV, Carlisle TW, Todd CC, Oates Jr RM. Effects of the Transcendental Meditation program on stress reduction, health, and employee development: A prospective study in two occupational settings. Anxiety, Stress and Coping. 1993;6(3):245-62.

74. Eisenberger R, Huntington R, Hutchison S, Sowa D. Perceived organizational support. Journal of Applied psychology. 1986;71(3):500.

75. Eisenberger R, Armeli S, Rexwinkel B, Lynch PD, Rhoades L. Reciprocation of perceived organizationa support. Journal of applied psychology. 2001;86(1):42.

76. Eisenberger R, Stinglhamber F. Perceived organizational support: Fostering enthusiastic and productive employees: American Psychological Association; 2011. 
77. Brown LA, Roloff ME. Perceived Organizational Support. The International Encyclopedia of Interpersonal Communication. 2015:1-10.

78. Rhoades L, Eisenberger R. Perceived organizational support: a review of the literature. Journal of applied psychology. 2002;87(4):698.

79. Eisenberger R, Malone GP, Presson WD. Optimizing perceived organizational support to enhance employee engagement. Society for Human Resource Management and Society for Industrial and Organizational Psychology. 2016:2-22.

80. Fuller JB, Barnett T, Hester K, Relyea C. A social identity perspective on the relationship between perceived organizational support and organizational commitment. The Journal of Social Psychology. 2003;143(6):789-91.

81. Lestariningsih M, editor Self Efficacy and Achievement Motivation on Performance with Perceived Organizational Support Moderation (A study on private university lecturer with" A" Accreditation Kopertis Region VII East Java). 2017 International Conference on Organizational Innovation (ICOI 2017); 2017: Atlantis Press.

82. Weiss HM, Cropanzano R. Affective events theory: A theoretical discussion of the structure, causes and consequences of affective experiences at work. 1996.

83. Hur W-M, Won Moon T, Jun J-K. The role of perceived organizational support on emotional labor in the airline industry. International Journal of Contemporary Hospitality Management. 2013;25(1):105-23.

84. Liu J-y, Yang J-p, Yang Y, Liu Y-h. The relationships among perceived organizational support, intention to remain, career success and self-esteem in Chinese male nurses. International Journal of Nursing Sciences. 2015;2(4):389-93.

85. Lu H, Barriball KL, Zhang X, While AE. Job satisfaction among hospital nurses revisited: a systematic review. International journal of nursing studies. 2012;49(8):101738.

86. Chen H-T. Theory-driven evaluations: Need, difficulties, and options. Evaluation Practice. 1994;15(1):79-82.

87. Liu J, Liu Yh. Perceived organizational support and intention to remain: The mediating roles of career success and self-esteem. International journal of nursing practice. 2016;22(2):205-14.

88. Becker TE. Foci and bases of commitment: are they distinctions worth making? Academy of management Journal. 1992;35(1):232-44.

89. Eisenberger R, Fasolo P, Davis-LaMastro V. Perceived organizational support and employee diligence, commitment, and innovation. Journal of applied psychology. 1990;75(1):51.

90. Kurtessis JN, Eisenberger R, Ford MT, Buffardi LC, Stewart KA, Adis CS. Perceived organizational support: A meta-analytic evaluation of organizational support theory. Journal of management. 2017;43(6):1854-84H Poor, An Introduction to Signal Detection and Estimation. New York: Springer-Verlag, 1985, ch. 4.

91. Cho S, Johanson MM, Guchait P. Employees intent to leave: A comparison of determinants of intent to leave versus intent to stay. International Journal of Hospitality Management. 2009;28(3):374-81.

92. Cheung MF. The mediating role of perceived organizational support in the effects of interpersonal and informational justice on organizational citizenship behaviors. Leadership \& Organization Development Journal. 2013;34(6):551-72.

93. Hassan S, Ul Hassan M. Testing the mediating role of perceived organizational support between leadership styles, organizational justice and employees' behavioral outcomes. Pakistan Journal of Commerce and Social Sciences (PJCSS). 2015;9(1):131-58

94. Khan R, Ghufran H. The Mediating Role of Perceived Organizational Support between Qualitative Job Insecurity, Organizational Citizenship Behavior and Job Performance. J Entrepren Organiz Manag. 2018;7(228):2.

95. McGhee P, Grant P. Spirituality and ethical behaviour in the workplace: Wishful thinking or authentic reality EJBO-Electronic Journal of Business Ethics and Organization Studies. 2008.

\section{AUTHORS PROFILE}

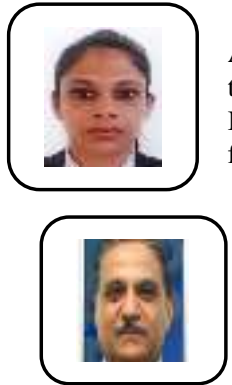

Ayshani Weeratunga is a $\mathrm{PhD}$ student attached to Asia Pacific University (APU) and has 2 years of teaching experience. She is a postgraduate in International Business Management and a CIMA passed finalist and has industrial experience in Sri Lanka.

Jugindar Singh Kartar Singh is a Senio Lecturer attached to Asia Pacific University (APU) and has 5 years of teaching and training experience. He has vast industrial experience and held leadership positions in large Banks in Malaysia. With a postgraduate in Business Administration, he has written articles and presented several papers in international and national conferences. 